Syracuse University

SURFACE at Syracuse University

\title{
Worldwide Population Aging: Endogenous Policy Formation and Capital Market Transmissions in the Presence of Symmetric Demographic Shocks
}

Mehmet Serkan Tosun

University of Nevada-Reno, Economics Department ; Institute for the Study of Labor (IZA), tosun@unr.edu

Follow this and additional works at: https://surface.syr.edu/cpr

Part of the Economics Commons

\section{Recommended Citation}

Tosun, Mehmet Serkan, "Worldwide Population Aging: Endogenous Policy Formation and Capital Market Transmissions in the Presence of Symmetric Demographic Shocks" (2000). Center for Policy Research. 128.

https://surface.syr.edu/cpr/128

This Working Paper is brought to you for free and open access by the Maxwell School of Citizenship and Public Affairs at SURFACE at Syracuse University. It has been accepted for inclusion in Center for Policy Research by an authorized administrator of SURFACE at Syracuse University. For more information, please contact surface@syr.edu. 
ISSN 1525-3066

\title{
Center for Policy Research
}

Working Paper No. 27

\section{WorldWide Population AgING: Endogenous \\ POLICY FORMATION AND CAPITAL MARKET \\ Transmissions in the Presence of \\ SYMMETRIC DEMOGRAPHIC SHOCKS \\ Mehmet Serkan Tosun}

\author{
Center for Policy Research \\ Maxwell School of Citizenship and Public Affairs \\ Syracuse University \\ 426 Eggers Hall \\ Syracuse, New York 13244-1020 \\ (315) 443-3114 | Fax (315) 443-1081 \\ e-mail: ctrpol@syr.edu
}

June 2000

$\$ 5.00$

Up-to-date information about CPR's research projects and other activities is available from our World Wide Web site at www-cpr.maxwell.syr.edu. All recent working papers and Policy Briefs can be read and/or printed from there as well. 


\title{
CENTER FOR POLICY RESEARCH - Spring 2000
}

\author{
Timothy M. Smeeding, Director \\ Professor of Economics \& Public Administration
}

\section{Associate Directors}

\author{
Margaret M. Austin \\ Associate Director, \\ Budget and Administration \\ Douglas Wolf \\ Professor of Public Administration \\ Associate Director, Aging Studies Program
}

\author{
Douglas Holtz-Eakin \\ Chair, Professor of Economics \\ Associate Director, Center for Policy Research \\ John Yinger \\ Professor of Economics and Public Administration \\ Associate Director, Metropolitan Studies Program
}

\section{SENIOR RESEARCH ASSOCIATES}

Dan Black

Economics

Stacy Dickert-Conlin

William Duncombe

Thomas Dunn.

Gary Engelhardt.

Deborah Freund

Vernon Greene

Leah Gutierrez

Madonna Harrington Meyer

Christine Himes

Jacqueline Johnson

Bernard Jump

Duke Kao.
Economics

Public Administration

Economics

Economics

Public Administration

Public Administration

Public Administration Sociology Sociology Sociology

. Public Administration Economics
Eric Kingson Social Work Thomas Kniesner .......................................Economics Jeff Kubik. Jerry Miner John Moran Jan Ondrich John Palmer Lori Ploutz-Snyder Grant Reeher Stuart Rosenthal Jodi Sandfort. Michael Wasylenko Assata Zerai.
Economics Economics Economics Economics Public Administration Health and Physical Education . Political Science Economics Public Administration Economics Sociology

\section{GRADUATE ASSOCIATES}

Matthew Andrews

Yvonne Arsenault

Reagan Baughman

Robert Bifulco.

Christine Caffrey

Julie Dombrowski

Karla English.

Amy Ferraro

Seth Giertz

Andrzej Grodner

Tess Heintze

Pam Herd.
Public Administration

Public Administration .Economics

Public Administration Sociology Sociology

Public Administration Public Administration Economics Economics Public Administration Sociology
Peter Howe Economics

Alyssa Hundrup

Kwangho Jung

Young Sun Kwon.

James Laditka

Xin Li

Donald Marples

Neddy Matshalaga

Adriana Sandu

Shalini Sharma

Mehmet Serkan Tosun

James Williamson.
Public Administration
Public Administration Economics Public Administration Economics Economics Sociology Public Administration Economics Economics Economics

\section{STAFF}

JoAnna Berger

Receptionist

Martha Bonney Publications and Events Coordinator

Karen Cimilluca.

Kati Foley ....

Esther Gray....
Denise Paul.

Mary Santy Debbie Tafel.

Ann Wicks Lobrenzo Wingo
Editorial Assistant, NTJ Secretary Secretary to the Director Administrative Secretary .Computer Consultant 


\section{Abstract}

This paper examines the transition effects of population aging in more developed regions that is also expected to occur in developing regions in the near future. We address these effects by exploring the influences of internationally mobile capital and a politically responsive fiscal policy in a two-country overlapping generations model. Our results show that the combination of capital mobility and endogenous fiscal policy play an important role in how economies respond to population aging. Capital mobility has consumption smoothing effects but endogenous fiscal policy is the key factor in creating asymmetries between countries. The interaction of the two may even account for a change in the pattern, in addition to a change in the size, of the effects of population aging on economic growth and welfare when compared to closed economy and exogenous fiscal policy models. We find that even when the demographic shock in the two regions is symmetric, reaction to this shock depends on the timing of the shock. Overall, the late, developing country demographic shock produces relatively more favorable economic outcomes worldwide. Finally, our analysis of the timing of developing country aging indicates that an early aging scenario is more beneficial for both regions. 
The global economy is experiencing major changes as a consequence of a demographic transition in which the populations of developed nations are aging. Less well understood is the fact that developing countries are next in this aging trend. Figure 1 shows the demographic difference between more developed and developing regions. The projected changes in the oldage dependency ratio between 1990 and 2150 indicate that population aging will be more dramatic in more developed regions until 2050. Developing regions are expected to experience serious population aging between 2050 and 2150, during which time the dependency ratio levels off in more developed regions. Thus, population aging is not confined to more developed regions; sooner or later populations of all nations are expected to age.

An important and widely ignored characteristic of the recent aging trend is that it influences fiscal policy decision making concurrently with rapid global capital market integration. In a world connected by an international capital market, population aging in one region of the world leads to capital flows by altering saving and consumption behavior and, by extension, changes fiscal policy. An endogenously changing fiscal policy in turn affects human capital accumulation by changing government spending for public goods such as education that serve as inputs to human capital. Through these channels, population aging is expected to have strong growth and welfare implications. In this paper, I examine the transition effects of population aging that is occurring in more developed regions and that is expected to occur in developing regions in the near future. The paper has two goals. The first goal is to establish the roles of international capital mobility, a politically responsive fiscal policy, and the interaction of the two in explaining the transition effects of population aging. Demographic changes in the two regions at different periods affect the political process of determining fiscal policies and lead to capital flows by creating interest rate differentials between countries. Thus, we expect to see 
both domestic and global effects of these demographic changes. The second goal is to compare the effects of aging under different aging scenarios for the developing regions. Since developing country aging is based on population projections, an analysis on the timing of developing country aging will tell us how our results might change if actual outcomes differ from projections.

Our results indicate that international capital mobility and endogenous fiscal policy together may account for a change in the pattern, in addition to a change in the size, of the effects of population aging on economic growth and welfare when compared to closed economy and exogenous fiscal policy models. We find that even when the demographic shock in the two regions is symmetric, reaction to this shock depends on the timing of the shock. Overall, the late, developing country demographic shock produces relatively more favorable economic outcomes worldwide. Finally, our analysis of the timing of developing country aging indicates that an early aging scenario is more beneficial for both regions.

The paper is structured as follows. The next section reviews the recent literature on population aging, followed by a description of a two-country, two-period overlapping generations model. The paper then examines dynamic capital stock transitions between preaging and post-aging steady states analytically. Transition analysis requires simulation; I then describe the parameters used in the simulation study and present simulation results together with a sensitivity analysis in the next section followed by my concluding remarks.

\section{Previous Literature}

A number of studies examine the macroeconomic effects of population aging. Recent theoretical studies generally lack consideration of effects that emerge from international capital mobility. However, by allowing for endogenous fiscal policy, some of these studies emphasize 
the importance of the simultaneity of government policies and the demographic structure of voters. Holtz-Eakin (1993), Meijdam et al. (1996), and Holtz-Eakin, Lovely and Tosun (2000) are closely related to this paper in terms of the fiscal policy aspect of the model structure. HoltzEakin (1993), using a modified version of the standard overlapping generations model, allows for endogenous fiscal policy. The author conducts a series of steady state simulations and shows that demographic change has significant impact on the growth of the economy as well as on government expenditure and taxation. Holtz-Eakin, Lovely and Tosun (2000) address in a closed economy setting how government spending for public education is affected by population aging. The study shows that even though demographic shift favors voters with a lower preference for education spending, reduced taxes may raise capital per worker enough to raise education spending. Meijdam et al. (1996), uses a similar approach to examine, in a closed economy framework, the effect of aging on the economy in general and on the evolution of public pension schemes. However, this study does not model the political process of fiscal policy determination explicitly.

Empirical studies generally use three different types of models. One of these is the CassRamsey-Solow growth model. Cutler et al. (1990) and Börsch-Supan (1996) are recent examples of this type. They both model capital flows within the OECD region. Cutler et al. show that capital flows change the size rather than the pattern of the effects of aging on consumption and they predict higher initial consumption than in autarky for the United States. Börsch-Supan predicts considerable capital flows to slowly aging Southern European Periphery, particularly to Turkey, within the OECD area. Neither of these studies models fiscal policy as endogenously determined with aging. Another group of studies employs multi-regional dynamic macroeconomic models that build on the consumption model of "perpetual youth" by Blanchard (1985). Of these, Masson and Tryon (1990) is a macroeconometric model that allows for capital flows between industrialized nations. They combine the effect of a higher dependency ratio and 
higher government expenditures due to aging. However, they obtain the annual series of government expenditures by interpolating estimates from another study. Thus, they do not treat fiscal policy as endogenous. Turner et al. (1998) employ the OECD "Minilink" model (a structural dynamic macro model). They allow for capital flows between a group of industrialized countries and the rest of the world, which they divide between "fast-aging" and "slow-aging" countries. They model government behavior by introducing a fiscal reaction function in which the tax rate adjusts gradually to close the gap between current government debt and its exogenous target in the long run. However, in this model public expenditures on education are assumed to change, simply in proportion to the change in population aged less than 15 years old. Although there is a tendency towards allowing for international capital flows, empirical studies either treat fiscal policy as exogenous or they model it in a rather simplified fashion.

In the light of this review, we intend to analyze the effects of aging by focusing on the capital flows between regions. Unlike the empirical studies mentioned above, we will treat fiscal policy as endogenously determined through a political process that is triggered by the changing demographic structure of voters.

\section{The Model}

\section{Modeling Strategy}

In this section, we describe our modeling strategy by providing details on the three distinct features of our approach. First, this paper employs an extended version of the twoperiod overlapping generations model with perfect foresight. By explicitly tracing the life-cycle of savers, overlapping generations models enable a generational or cohort welfare analysis of 
population aging. This implies that demographic transitions, which take the form of changing relative cohort size, can be important determinants of national saving and the current account.

Secondly, we explicitly model a political process for fiscal policy making. One issue in recent discussions of aging is the potential generational conflict generated by the need to share society's resources between non-working elderly and the younger working population. For example, Poterba (1997) provides evidence from the United States that older citizens prefer lower levels of public spending for education, an expenditure that primarily benefits the young. Similarly Kahn (2000) shows that population demographics is an important determinant of the support for environmental regulation. His results indicate that senior citizens are more likely to find government spending for environment too high. To highlight the effect of aging on economic growth, we maximize this generational conflict by considering only government expenditure for working young, ignoring social security payments to the old. In order to simulate this distributional conflict, a political process must be posited. To make the political process of fiscal policy determination rich, interesting, and tractable, we use a median voter framework ${ }^{1}$ with voter heterogeneity. Voter heterogeneity is introduced by assuming a distribution of genetic ability levels for the working generation. The ability level of the individual will, in turn, determine the value she receives from a publicly provided good such as education.

Finally the third aspect of our modeling strategy is a focus on transitions between preaging and post-aging steady states. We first introduce demographic change in one country (signifying more developed regions) as a drop in their population growth rate. Consistent with the worldwide aging trend in Figure 1, the population growth rate drops in the other country (signifying developing regions) as well after two model periods. Population growth rates of the two countries are equal in both the initial and the final steady states ${ }^{2}$. Therefore, our analysis is of transition between these two steady states. 
Our model extends the basic Diamond overlapping generations model ${ }^{3}$ in two ways. First, it is a two-country world economy model similar to Buiter (1981) in which countries are perfectly symmetric in the initial steady state equilibrium. Second, it models political decision making for fiscal policy in order to examine political economy related effects of aging. With an increase in the dependency ratio, ${ }^{4}$ fiscal policy shifts towards the preferences of the older generation. This combines with the effect of international capital mobility when demographic asymmetries (different population growth rates) between countries or regions are present. Internationally mobile capital is the intermediary in spreading the effects of aging globally. For clarity, we first present the model for one country only. Then we describe the two-country world equilibrium. However, this analysis also applies in an asymmetric, two-region model.

\section{Household Behavior}

Individuals live for two periods and seek to maximize a lifetime utility function,

$$
U=\ln C_{j t}+\left(\frac{1}{1+\delta}\right) \ln C_{j t+1},
$$

here $j$ indexes individuals, $C_{j t}$ is consumption when young, and $C_{j t+1}$ is consumption when old. The period-specific budget constraints in the first and the second periods are:

First period: $C_{j t}\left(a_{j}\right)+S_{j t}\left(a_{j}\right)=\theta_{t} w_{t} h_{t}\left(a_{j}\right)$

Second Period: $C_{j t+1}\left(a_{j}\right)=\left(1+\theta_{t+1} r_{t+1}\right) S_{j t}\left(a_{j}\right)$,

here $\theta_{\mathrm{t}}=\left(1-\tau_{t}\right), h_{t}$ is the human capital of the individual, $a_{j}$ is the ability level of individual $j$, and $\tau$ is the rate of income taxation.

Tax policy is a flat tax on the labor income of the young and the capital income of the old. Capital income taxation follows a source-based system. I also assume there is a continuous distribution of abilities that is replicated in each new generation. The ability level of individual $\mathrm{j}$ 
is denoted by $a_{j}$. This ranges from 0 to 1 and the density function of abilities is denoted by $f(a)$ where by definition:

$$
\int_{0}^{1} f(a) d a=1 .
$$

Human capital is accumulated from the interaction of ability level (a) of the individual and government spending per worker $(\mathrm{g})$ :

$$
h\left(a_{j}\right)_{t}=\Phi\left[a_{j} g_{t}+1\right]^{\psi}
$$

The form of the human capital function is chosen so that individuals with the lowest ability $\left(a_{j}=0\right)$ will contribute to the economy in terms of human capital (see Holtz-Eakin, Lovely, and Tosun 2000). From the maximization of (1) subject to (2) and (4); we get the familiar first order condition:

$$
C_{j t}\left(a_{j}\right)=\frac{1+\delta}{\left(1+r_{t+1} \theta_{t+1}\right)} C_{j t+1}\left(a_{j}\right) .
$$

Using (5) and (2), we derive the optimal saving of an individual $\mathrm{j}$ :

$$
S_{j t}\left(a_{j}\right)=\frac{1}{2+\delta} \theta_{t} w_{t} h_{t}\left(a_{j}\right)
$$

Saving of an individual depends on net labor earnings but it is independent of the interest rate. This is due to the Cobb-Douglas form of the utility function. Given (5) and (6), it is easy to derive consumption functions in each period:

$$
\begin{aligned}
& C_{j t}\left(a_{j}\right)=\frac{1+\delta}{2+\delta} \theta_{t} w_{t} h_{t}\left(a_{j}\right) \\
& C_{j t+1}\left(a_{j}\right)=\frac{\left(1+r_{t+1} \theta_{t+1}\right)\left(\theta_{t} w_{t} h_{t}\left(a_{j}\right)\right)}{2+\delta} .
\end{aligned}
$$




\section{Political Process}

The consumption and saving decisions, as seen above, depend on human capital, which is in turn determined by government spending (see equation 4). By plugging these into (1), we get the indirect utility function which each voter maximizes in determining his or her preferred tax rate, subject to the government budget constraint $\left(\tau_{t} y_{t}=g_{t}\right)$. The preferred tax rate of individual $j$ when young is:

$$
\tau_{j t}\left(a_{j}\right)=\frac{a_{j} \psi y_{t}-1}{(1+\psi) a_{j} y_{t}} .
$$

Equation (8) is the tax rate each individual prefers based on her ability level. This preferred tax rate is increasing in both ability level $a$ and in aggregate income $y$. Because the old do not derive any benefit from publicly provided education and there are no bequests in the model, they incur a cost without enjoying any benefits. Therefore, their preferred tax rate will always be zero, regardless of their ability.

At each period of the model, a cohort of size $N_{t}$ is born. Then total population in each period is $N_{t-1}+N_{t}$ where $N_{t}=\left(1+\eta_{t}\right) N_{t-1}$ and $\eta_{t}$ is the population growth rate at period $t$. Given this, the median voter is defined by

$$
N_{t-1}+N_{t} \int_{0}^{m} f(a) d a=\frac{N_{t-1}+N_{t}}{2}
$$

here $m$ is the ability level of the median voter.

With population aging, the median voter becomes a lower ability person (see Appendix II) and the preferred tax rate of the median voter is lower. The intuition behind this is as follows: as the population ages (dependency ratio rises), older people will need fewer young voters to form a majority. These young voters are the ones at the lower end of the ability 
distribution. They prefer lower taxes than higher ability people because their return from public education is lower.

\section{Producers' Behavior}

Each country produces a single good using a Cobb-Douglas production technology.

$$
Y_{t}=\Lambda H_{t}^{\beta} K_{t}^{1-\beta}
$$

here $K$ is capital stock and $H$ is aggregate supply of human capital. The aggregate supply of human capital is:

$$
H_{t}=N_{t} \int_{0}^{1} h(a) f(a) d a .
$$

Competitive factor markets require that real wage and interest rates are equal to the marginal products of labor and capital respectively. Therefore, factor demand equations are:

$$
\begin{aligned}
& w_{t}=\beta \Lambda\left(\frac{k_{t}}{h_{t}}\right)^{1-\beta} \\
& r_{t}=(1-\beta) \Lambda\left(\frac{k_{t}}{h_{t}}\right)^{-\beta} .
\end{aligned}
$$

Here, $k_{t}=K_{t} / N_{t}$ and $h_{t}=H_{t} / N_{t}$ are capital stock per worker and human capital per worker, respectively. Human capital per worker, using (4) and (11), is

$$
h_{t}=\Phi \int_{0}^{1}\left(a g_{t}+1\right)^{\psi} f(a) d a \text {. }
$$

Using (6) and (14), we can express saving per worker as

$$
s_{t}=\left(\frac{1}{2+\delta}\right) \theta_{t} w_{t} \Phi \int_{0}^{1}\left(a g_{t}+1\right)^{\psi} f(a) d a
$$

\section{World Equilibrium}

To close our dynamic model, we must specify an international goods market condition and an international capital flow constraint. I assume there is perfect international financial 
capital mobility. In each country, claims to domestic and foreign capital are perfect substitutes. International goods market equilibrium requires that world saving is equal to world investment. The domestic capital stock per worker may be higher (lower) than the domestic saving per worker, implying international capital flows. Writing this in per worker terms, international goods market equilibrium implies:

$$
k_{t+1}^{A}+\left[\prod_{i=0}^{t} \frac{\left(1+\eta_{i+1}^{B}\right)}{\left(1+\eta_{i+1}^{A}\right)}\right] k_{t+1}^{B}=\frac{s_{t}^{A}}{1+\eta_{t+1}^{A}}+\left[\frac{\prod_{i=1}^{t \neq 0}\left(1+\eta_{i}^{B}\right)}{\prod_{i=0}^{t}\left(1+\eta_{i+1}^{A}\right)}\right] s_{t}^{B} .
$$

Here I assume that initial population sizes are the same in both countries (i.e., $N_{0}^{A}=N_{0}^{B}$ ). In our model, capital income is taxed where income is earned. Thus, we employ a source-based system of capital income taxation for both countries. This implies that net-of-tax interest rates are equalized in equilibrium. Therefore, the international capital flow constraint is:

$$
r_{t+1}^{A}\left(1-\tau_{t+1}^{A}\right)=r_{t+1}^{B}\left(1-\tau_{t+1}^{\mathrm{B}}\right)
$$

Capital will move between countries until both (16) and (17) obtain. We complete our two-country model by introducing balance of payments identities. Balance of payments accounts are especially important in tracing the saving-investment imbalances between countries. Since this is a two-country model, balance of payments of the two countries must sum to zero. Therefore, we have $C A_{t}^{A}=-C A_{t}^{B}, B O T_{t}^{A}=-B O T_{t}^{B}$, and $F I_{t}^{A}=-F I_{t}^{B}$; where $C A, B O T$, and FI stand for current account, balance of trade, and net foreign income, respectively. The current account is defined as the difference between national product and domestic absorption. National product consists of domestic product and net foreign income. Domestic absorption equals the sum of consumption and domestic capital accumulation less taxes. I assume that the consumption good can move costlessly between countries. Given this definition, the current account equation can be written as. ${ }^{5}$ 


$$
C A_{t}=y_{t}\left(1-\tau_{t}\right)+r_{t}\left(1-\tau_{t}\right)\left[\frac{s_{t-1}}{1+\eta_{t}}-k_{t}\right]-c_{1 t}-\frac{c_{2 t}}{1+\eta_{t}}-\left[\left(1+\eta_{t+1}\right) k_{t+1}-k_{t}\right]
$$

The current account is the sum of balance of trade and net foreign income $\left(C A_{t}=B O T_{t}+F I_{t}\right){ }^{6}$ Because this is a one-sector model, "international trade and international lending and borrowing are part and parcel of the same transaction" (Buiter 1981). The only way for a country to consume and invest more than it produces (have a trade deficit) is to hold a net ownership of claims on foreign capital (receive positive net foreign income).

\section{The Experiment}

To focus on the role of demographic transition, I assume that the countries are initially identical. As a benchmark, country A is the country that undergoes demographic transition first and it has a lower population growth rate than country B in the first two periods. Country B's population growth rate decreases to country A's growth rate in the third period and the two growth rates are equalized thereafter. Because the population growth rate changes, the ability level of the median voter also changes. This leads to a change in government spending for education, human capital accumulation, capital accumulation, and income per worker. Thus, a change in the ability level of the median voter through demographic shift induces an economic transition. As shown in the appendix, when the population growth rate falls (increased dependency ratio), the ability level of the median voter goes down as well. All else equal, this political transition would reduce provision of the public good. However, if the tax rate decreases, national saving, and thus, physical capital accumulation will be enhanced. This may create a positive effect on income per worker, government spending per worker and human capital per worker. When the feedback effect from human capital accumulation dominates the negative effect of a lower preferred tax rate, demographic shift may induce higher income per worker, higher capital stock per worker, and higher human capital and government spending per 
worker. However, in an international setting changes in the interest rate in the aging country due to changes in income per worker and capital per worker may lead to capital flows between countries. In the next section, I will examine the transition effects of aging on capital accumulation in both countries. I will also address the issue of stability of the dynamic system.

\section{Transition Dynamics in Response to Population Aging}

\section{Stability and Capital Stock Transitions}

Transitions can be examined by tracing the behavior of the capital stock over time. For this analytical approach, we totally differentiate the equations given by (8), (10), and (12) through (15) for each country, and (16) and (17), which can be reduced to a vector difference equation:

$$
F_{t+1}=\Omega F_{t}+\hat{\Omega} N_{t}
$$

where

$$
\begin{aligned}
& F_{t+1}=\left[\begin{array}{c}
d k_{t+1}^{A} \\
d k_{t+1}^{B}
\end{array}\right], \\
& F_{t}=\left[\begin{array}{c}
d k_{t}^{A} \\
d k_{t}^{B}
\end{array}\right], N_{t}=\left[\begin{array}{c}
d \eta_{t}^{A} \\
d \eta_{t}^{B} \\
d \eta_{t+1}^{A} \\
d \eta_{t+1}^{B}
\end{array}\right]
\end{aligned}
$$

and

$$
\Omega=\left[\begin{array}{cc}
M & M \\
M & M
\end{array}\right], \hat{\Omega}=\left[\begin{array}{llll}
Z_{4} & Z_{4} & Z_{2}-\frac{Z_{3}}{Z_{1}} & Z_{2}+\frac{Z_{3}}{Z_{1}} \\
Z_{4} & Z_{4} & Z_{2}+\frac{Z_{3}}{Z_{1}} & Z_{2}-\frac{Z_{3}}{Z_{1}}
\end{array}\right]
$$

The vector difference equation (19) is used for two purposes. First, for a constant population growth across periods, it can be used to examine the stability of the dynamic system. 
$\Omega$ summarizes the relationship between $k_{t}$ and $k_{t+1}$. Secondly, for a given capital stock in period $t$, we examine the effect of a change in the population growth rate on the capital stock in period $t+1$. I will address each of these below.

In order to analyze the stability of the dynamic system, we examine the matrix $\Omega$ in which $M=\frac{\alpha\left(1-\frac{\tau^{*}}{1-\tau^{*}} \varepsilon_{\tau y}\right)}{2 P}$, and $P=1-\left[(1-\alpha) \varepsilon_{h g}\left(1+\varepsilon_{\tau y}\right)\right]$ in $M$. Political equilibrium is locally stable when $P>0$ and the system is dynamically stable when $2 M<1$ (see appendix for derivation of the stability conditions). ${ }^{7}$ In line with our benchmark experiment described above, we can see how the dynamic system will reach a steady state after a demographic transition.

Expanding (19) for a fixed level of initial capital stock per worker, we can write (19) for $t=0,1,2$ as:

$$
\begin{aligned}
& F_{1}=\Omega F_{0}+\hat{\Omega} N_{0} \\
& F_{2}=\Omega^{2} F_{0}+\Omega \hat{\Omega} N_{0}+\hat{\Omega} N_{1} \\
& F_{3}=\Omega^{3} F_{0}+\Omega^{2} \hat{\Omega} N_{0}+\Omega \hat{\Omega} N_{1}+\hat{\Omega} N_{2}
\end{aligned}
$$

Then generalizing this for $t>2$,

$$
F_{t+1}=\Omega^{t+1} F_{0}+\Omega^{t} \hat{\Omega} N_{0}+\Omega^{t-1} \hat{\Omega} N_{1}+\ldots+\Omega \hat{\Omega} N_{t-1}+\hat{\Omega} N_{t}
$$

where $F_{0}=\left[\begin{array}{l}d k_{0}^{A} \\ d k_{0}^{B}\end{array}\right]=\left[\begin{array}{l}0 \\ 0\end{array}\right]$.

Notice that the coefficients of the terms in (21) resemble a geometric series. In line with our assumptions regarding the demographic transition we can assume that $N_{3}=N_{4}=\ldots=N_{t-1}=N_{t}$. Using this, we can write (21) as:

$$
F_{t+1}=\Omega^{t} \hat{\Omega} N_{0}+\Omega^{t-1} \hat{\Omega} N_{1}+\Omega^{t-2} \hat{\Omega} N_{2}+\left(\Omega^{0}+\Omega^{1}+\Omega^{2}+\ldots \Omega^{t-3}\right) \hat{\Omega} N_{t}
$$


As $t \rightarrow \infty$, the first three terms in the above expression converge to zero and since all the elements of the matrix $\Omega$ is less than 1 by dynamic local stability, the geometric series in parentheses converges to $(I-\Omega)^{-1}$. Thus, assuming that $d \eta_{t}^{A}=d \eta_{t}^{B}=d \eta$ (identical changes in the steady state population growth rates), as $t \rightarrow \infty,(22)$ can be written as:

$$
\underset{\substack{t \rightarrow+\infty \\ t \rightarrow \infty}}{F_{1}}=(I-\Omega)^{-1} \hat{\Omega} N
$$

By using $\Omega$, and $\hat{\Omega}$, and converting (23) back to the scalar form, we get the increase in capital per worker from the initial steady state to the post-demographic transition steady state ${ }^{8}$ :

$$
\frac{d k^{A}}{d \eta}=\frac{d k^{B}}{d \eta}=\frac{2\left(Z_{2}+Z_{4}\right)}{1-2 M}
$$

where

$$
Z_{2}=\frac{-k^{*}}{2\left(1+\eta^{*}\right)},
$$

and

$$
Z_{4}=\frac{(1-\alpha) s^{*} \varepsilon_{h g} \varepsilon_{\tau a}\left(1-\frac{\varepsilon_{\tau y} \tau^{*}}{1-\tau^{*}}\right)-s^{*} \varepsilon_{\tau a} \frac{\tau^{*}}{1-\tau^{*}} P}{2 P \eta^{*}\left(1+\eta^{*}\right)^{2}}
$$

$Z_{2}$ is negative, while the sign of $Z_{4}$ is indeterminate which makes the sign of the derivatives in (24) indeterminate". $Z_{2}$ is the "direct saving effect"10 of a change in the population growth rate on capital per worker for a given ability of median voter. Holding the ability of the median voter fixed, a decrease in the population growth rate increases capital per worker by spreading the same saving over fewer workers. $Z_{4}$ is the "indirect saving effect" 11 of a change in the ability of median voter on capital per worker. A decrease in the median voter's ability, triggered by a decrease in the population growth rate, decreases wage income $(w h)$ while decreasing the tax rate. Thus, the net effect on net labor income and saving depends on the 
relative magnitudes of the effects on wage income and the tax rate. The total effect of a decrease in the population growth rate on the steady state capital per worker depends on how the political economy related effect $\left(Z_{4}\right)$ compares to the direct saving effect $\left(Z_{2}\right){ }^{12}$ Notice that $Z_{4}$ depends on the elasticity of the preferred tax rate with respect to income per worker $\left(\varepsilon_{\tau y}\right)$, elasticity of the preferred tax rate with respect to median voter's ability $\left(\varepsilon_{\tau a}\right)$, and the elasticity of human capital with respect to government spending per worker $\left(\varepsilon_{h g}\right)$. ${ }^{13}$ When $\varepsilon_{\tau a}=0, Z_{4}$ is also equal to zero and steady state capital per worker unambiguously increases with a decrease in $\eta$. This is because zero elasticity eliminates completely the feedback effects from an endogenous fiscal policy. $Z_{4}$ is increasing in $\varepsilon_{h g}$ which means that a decrease in government spending decreases human capital per worker more as $\varepsilon_{h g}$ gets bigger, leading to a greater decrease in labor income, ceteris paribus.

Using (19) and (21) for both countries, the dynamic solution of capital per worker caused by a change in the population growth at any period during transition is given by:

$$
\begin{aligned}
& \frac{d k_{t+1}^{A}}{d \eta_{t+1}^{A}}=\frac{d k_{t+1}^{B}}{d \eta_{t+1}^{B}}=\left(Z_{2}-\frac{Z_{3}}{Z_{1}}\right) \quad \frac{d k_{t+1}^{A}}{d \eta_{t+1}^{B}}=\frac{d k_{t+1}^{B}}{d \eta_{t+1}^{A}}=\left(Z_{2}+\frac{Z_{3}}{Z_{1}}\right) \\
& \frac{d k_{t+1}^{A}}{d \eta_{t}^{A}}=\frac{d k_{t+1}^{A}}{d \eta_{t}^{B}}=\frac{d k_{t+1}^{B}}{d \eta_{t}^{B}}=\frac{d k_{t+1}^{B}}{d \eta_{t}^{A}}=\left(2 M Z_{2}+Z_{4}\right)
\end{aligned}
$$

where

$$
\begin{aligned}
& Z_{1}=\frac{2\left[\alpha^{2} y^{*}\left[\left(1-\tau^{*}\right)-\varepsilon_{\tau y} \tau^{*}\right]-P y^{*}\left(1-\tau^{*}\right)\right]}{k^{*^{2}} P}, \\
& Z_{3}=\frac{(1-P) \alpha y^{*} \varepsilon_{\tau a}\left[\left(1-\tau^{*}\right)+\varepsilon_{\tau y} \tau^{*}\right]-\alpha y^{*} \varepsilon_{\tau} \tau^{*} P\left(1+\varepsilon_{\tau y}\right)}{\left(1+\varepsilon_{\tau y}\right) k^{*} P\left(1+\eta^{*}\right) \eta^{*}}
\end{aligned}
$$


In equation (25), $Z_{1}$ is the "direct net interest rate effect" (through capital changes) of a change in the population growth rate in one country and it is negative under the stability conditions $^{15}$. For a given ability of the median voter, an increase in capital per worker in one country depresses the net interest rate, which in turn has a negative effect on capital accumulation in that country, ceteris paribus.

$Z_{3}$ is the "indirect net interest rate effect" through a change in median voter's ability. The sign of $Z_{3}$ is indeterminate which makes the signs of the derivatives in (25) indeterminate as well. For a given level of capital, a decrease in the median voter's ability decreases the marginal productivity of capital by decreasing income, thus creating a negative effect on the net interest rate. However, it also decreases the tax rate, thus creating a counter effect on the net interest rate. Considering these together, $Z_{3} / Z_{1}$ can be interpreted as the net interest rate effect of a change in median voter's ability on capital per worker after controlling for the effect of capital stock changes on the interest rate $\left(Z_{1}\right)$.

We see in (25) that a change in one country's population growth rate has opposite effects on capital accumulation in two countries. This is due to the change in the net interest rate in one country. The momentary interest rate differential between the two countries will be eliminated by the flow of capital from the country with the lower net interest rate to the one with the higher one. To give an example, holding other effects constant, a decrease in the population growth in only country A at any point in time will decrease the net interest rate in country A as long as the decrease in tax rate is outweighed by the decrease in the interest rate. This, in turn will cause country A capital to flow to country B until the net interest rates are equalized. Notice that when $\varepsilon_{\tau a}=0, Z_{3}$ is also equal to zero which drives the net interest rate effect $\left(Z_{3} / Z_{1}\right)$ to zero. In addition to the interest rate effects mentioned above, capital per worker in period $t+1$ is also affected by saving in period $t$. Therefore, a change in population growth rate in period $t$ will 
affect capital per worker in period $t+1$ through a saving effect. This is depicted in (26). The argument is similar to the one for steady state changes. With a decrease in the population growth rate, the direct saving effect controlled for capital growth in period $t\left(2 M Z_{2}\right)$ increases capital per worker in period $t+1$ for a given level of median voter's ability. However, a decrease in median voter's ability will also affect saving by decreasing both the labor income and the tax rate, causing the net effect to be ambiguous.

\section{The Role of Capital Mobility and Endogenous Fiscal Policy in Capital Stock Transitions}

In order to explore the significance of open economy and endogenous fiscal policy effects, we compare the effects in (25) and (26) with analytic results from two alternative versions of this model. A comparison with closed economy shows the influence of capital mobility, while a comparison with an exogenous policy model indicates the importance of endogenous fiscal policy. Solutions for these models are:

Closed economy model: $\frac{d k_{t+1}^{A^{c}}}{d \eta_{t+1}^{A^{c}}}=2 Z_{2}$ and $\frac{d k_{t+1}^{A^{c}}}{d \eta_{t}^{A^{c}}}=2\left(2 M Z_{2}+Z_{4}\right)$.

Exogenous fiscal policy model: $\quad \frac{d k_{t+1}^{A^{f}}}{d \eta_{t+1}^{A^{f}}}=\frac{d k_{t+1}^{A^{f}}}{d \eta_{t+1}^{B^{f}}}=\frac{d k_{t+1}^{B^{f}}}{d \eta_{t+1}^{A^{f}}}=\frac{d k_{t+1}^{B^{f}}}{d \eta_{t+1}^{B^{f}}}=Z_{2}$

$$
\frac{d k_{t+1}^{A^{f}}}{d \eta_{t}^{A^{f}}}=\frac{d k_{t+1}^{A^{f}}}{d \eta_{t}^{B^{f}}}=\frac{d k_{t+1}^{B^{f}}}{d \eta_{t}^{A^{f}}}=\frac{d k_{t+1}^{B^{f}}}{d \eta_{t}^{B^{f}}}=2 M^{f} Z_{2}
$$

Comparing (25) and (26) with (27), we see that both the direct saving effect $\left(Z_{2}\right)$, and the indirect saving effect $\left(Z_{4}\right)$ are shared equally between the two countries when these economies are open. The interesting point here is that this result is independent of which country ages. Therefore, we can say that, by spreading the effects of aging between countries, internationally mobile capital partially offsets the effect of population aging that comes from its effects (direct and indirect) on saving. Comparing (25) and (26) with (27)-(29), we also see that the net interest 
rate effect $\left(Z_{3} / Z_{1}\right)$ is unique to our model, making this a combined effect of capital mobility and endogenous fiscal policy. Since this effect changes capital per worker in A and B in opposite directions, it is a major factor in creating an asymmetry between the two countries throughout the demographic transition. Through this effect, the pattern as well as the size of the effect of aging may change.

The analytical exercise above clearly indicates the importance of examining aging in an open economy setting. However, we would like to know both the direction and the magnitude of these effects and how sensitive they are to model parameters. In the next section, we present the results from a simulation of these models.

\section{Simulation of Transition Effects}

The simulation study consists of transition analysis of population aging in both countries at different time periods. We assume that both countries are at an identical steady state in period 0. Population aging is simulated by a decrease in the population growth rate (or an increase in the dependency ratio) from an annual 2 percent rate to an annual 1 percent rate. In our benchmark simulation, country A ages starting at period 1 while country B retains its demographic structure until period 3. The population growth rates between the two countries are equalized in period 3 and thereafter. The parameter values used in the numerical simulation are shown in Table 1. Notice that two parameters, the rate of time preference in the utility specification and the population growth rate, are adjusted to the length of the model period (30 years). In these simulations, we assume that the ability level, a, is distributed uniformly on the interval $[0,1]$. These parameter values and the timing of population aging mentioned above describe the benchmark simulation. A series of sensible values for the share of capital in output 
$(\alpha)$ and for the efficiency of education in raising human capital $(\psi)$ are chosen to conduct a sensitivity analysis as explained in a later section.

\section{Simulation Results}

As exposited above, with an increase in the dependency ratio older people will form a majority with fewer young people at the lower end of the ability distribution. Therefore, the ability of the median voter is lower than in country A, but unchanged in country B until period 3, after which it is the same in both countries. Figure 2 shows the implications of this on the preferred tax rate. In both countries, the tax rate decreases in the first period of their aging trend. We also see tax rate increases in both countries following this first period. This is due to income growth (see below) in both countries, and the fact that the preferred tax rate exhibits positive income elasticity. In our model, the lower tax rate in the aging country, ceteris paribus, causes lower government spending and this causes deterioration in human capital accumulation. We see in Figure 3 that human capital per worker decreases in country A in period 1 and in country B in period 3. However, again due to income growth, human capital increases in both countries following their first period of aging, and both countries end up with a higher steady state human capital per worker.

Above, we have shown that the effect of a decrease in population growth rate on capital per worker is indeterminate due to the political economy of a changing median voter. Figure 4 shows that with the parameter values chosen for simulation, the capital stock per worker increases in both countries throughout the entire transition. After the first demographic shock in country A, the abundance of capital per worker compared to a decreasing human capital per worker depresses the domestic interest rate in country A. At a lower interest rate, demand for capital increases in country B, causing capital to flow to country B. Capital per worker is higher in country B than in country A during the first two periods because the decrease in the ability of 
median voter in A depresses the net interest rate (Figure 5) in A even further causing more capital to flow to country B. The second demographic shock, which takes place in country B in period 3, boosts capital accumulation in both countries. The increase in capital per worker in the second shock is larger because both economies are growing prior to the second shock.

For a better understanding of the capital movements between countries, we examine the changes in the balance of payments accounts. We graph only the balance of payments of country A, as the balance of payments accounts in country B are just the opposite of country A. Due to our perfect foresight assumption, the decrease in country A's population growth rate in period 1 leads to a drop in period 0 domestic investment. We see in Figure 6 that starting at a zero net foreign income, this generates a current account surplus for country A in periods 0 and 1 . Thus, capital moves from country A to country B from period 0 to period 2 . This explains the increase in the capital stock per worker in country B in the first two periods as we have seen in Figure 4. This also leads to positive net foreign income for country A in periods 1 and 2 . With the arrival of the second demographic shock, however, country A incurs a large trade and current account deficit in period 2. This means that capital flows from country B back to country A from period 2 to period 3, leading to greater increase in capital stock per worker in country A in period 3. Also, in period 3, country A has negative net foreign income and a trade surplus. Because trade surplus outweighs negative net foreign income, country A has a current account surplus and capital flows from country A to country B again. However, since economic variables converge rapidly to their new steady state values after period 4, current accounts and trade accounts of both countries are balanced thereafter.

These results for capital per worker and human capital per worker tell us how income responds to the demographic transition. For the first demographic shock, due to the capital inflow to country B until period 2, both capital and human capital per worker increase in country B leading to an increase in income per worker in the first two periods. On the other hand, even 
though the capital per worker increases in A, human capital per worker decreases in period 1. The income transitions in Figure 7 show that the decrease in human capital dominates, leading to a decrease in the income per worker in country $\mathrm{A}$ in the first period. In the second period however, due to both capital and human per worker increases, income per worker increases in country A. When the second demographic shock hits country B, unlike the first shock, we see income growth in both countries. Thus, country B does not experience the same income deterioration as country A did in the first shock even though the shock itself is identical in both cases. This interesting result, which is a clear indication of asymmetric economic transitions of countries aging at different times, can be explained by the observation that economies are growing prior to the second demographic shock. ${ }^{16}$ Therefore, this "growth effect" partially offsets the adverse effects of population aging for country B.

Welfare effects of aging can be examined by defining welfare in period $t$ as the lifetime welfare of a person of generation $t .{ }^{17}$ Welfare of this person is composed of her consumption when young (in period $t$ ) and consumption when old (in period $t+1$ ). In order to examine welfare effects, we derive an indirect utility function by substituting consumption solutions in (7) into (1), and we integrate this over the ability distribution. To understand welfare changes, we will first examine consumption transitions. In Figure 8, we see that consumption of old persons of generations 0 and 2 decreases in both countries immediately after the two shocks. On the other hand, consumption of young persons of all generations increases in both countries throughout the entire demographic transition. The decrease in the consumption of old has to do with the perfect foresight assumption in our overlapping generations model. In periods 0 and 2, consumers internalize the steep decrease in the net of tax interest rate (see Figure 5) in periods 1 and 3. Thus, young persons who save in periods 0 and 2 will consume less from a given level of savings in their old age in periods 1 and 3. This result explains welfare changes in periods 0 and 2 . 
Figure 9 shows that welfare levels of generations 0 and 2 drop in both countries. However, notice that the decrease in welfare in period 2 is less pronounced than the decrease in period 0 . The answer to this puzzle lies at the increase in consumption of young in period 2 , which is again the consequence of an already growing economy prior to the second shock. As hinted by the simulation results in this section, international capital mobility and the political economy of a changing median voter are the key factors in understanding the effects of population aging on the economic transitions of countries. In the following section, we will sharpen our understanding by comparing the results presented above with the results from alternative versions of our model.

\section{Comparison with Alternative Versions}

We begin, in Table 2, by comparing the effects of demographic transitions in an open world economy to those in a world without capital mobility. We see that open economy results in columns (3), (4), and (5) are considerably different from the closed economy results in columns (1) and (2). The open economy results with exogenous fiscal policy in column 3 are identical for both countries. As mentioned in the analytical section, by affecting capital accumulation in both countries in opposite directions, a politically determined fiscal policy single-handedly creates asymmetric results for countries. On the other hand, comparing the closed economy results with the open economy results, we see that capital mobility acts as a shock absorber, spreading the effects of aging to both economies. While capital flows smooth consumption and welfare in country A for the first demographic shock, they smooth consumption and welfare in country B for the second shock. These results suggest that the interaction of open economy and endogenous fiscal policy changes the size of the effects of aging in a considerable way.

An even more striking result is that it is possible to change the pattern as well as the size

of these effects. Aging increases country A's income per worker in closed economy version, but 
it decreases first period income per worker in country $\mathrm{A}$ in our open economy model with endogenous fiscal policy. The explanation lies in the relatively smaller increase in the first period capital stock and greater decrease in first period human capital and government spending per worker in country A. Another change is seen in welfare transitions. Unlike the closed economy results, the open economy results in columns (3) and (4) show that the welfare of generation 0 in country in B and welfare of generation 2 in country A both decrease because of the decreases in old age consumption.

Finally, results in columns (3)-(5) show that there are transition asymmetries between the first and the second demographic shocks. In terms of welfare, both countries are better off in the second shock compared to the first one. This can be explained by the economic growth that is taking place prior to the second demographic shock. Therefore, even though the demographic shocks are symmetric (a decrease in population growth from 2 percent to 1 percent), the economic transitions are not.

\section{Sensitivity Analysis}

The simulations, described in the previous sections, are based on the parameter values presented in Table 1. Among those, the parameter of the human capital function $(\psi)$, which can be interpreted as the return, in terms of human capital, from government spending, is an important aspect of the model and the welfare results. Accordingly, in Table 3 we present the results of a sensitivity analysis for $\psi$. Higher values of $\psi$ are associated with higher values of the elasticity of human capital with respect to government spending per worker $\left(\varepsilon_{h g}\right)$ and lower values of the elasticity of the preferred tax rate with respect to median voter's ability $\left(\varepsilon_{\tau a}\right)$. Thus, for a high value of $\psi$, there will be a relatively smaller decline in the tax rate and government spending from a decrease in median voter's ability, while there will be a relatively greater human capital feedback from government spending for a given ability level. We see in 
columns (5) and (6) that, for $\psi=0.7$, countries overall have more favorable transitions, indicated by capital, income and welfare growth throughout the transition periods. However, for $\psi=0.35$, the decrease in government spending and human capital due to a decrease in median voter's ability is so large that there is even a decrease in capital per worker in period 2 in both countries. This leads to substantial welfare deterioration in periods 1 and 2 for country A and in period 2 for country B.

The qualitative results from the previous section are overall robust to different values of $\psi$. Our qualitative results are also robust to an alternative utility function. Simulations for a Constant Relative Risk Aversion (CRRA) utility function ${ }^{18}$ change only the size of the results presented in Table 3. However, our sensitivity analysis shows that while the open economy is more likely to change the pattern of the closed economy results for lower values of $\psi$, consumption and welfare smoothing effect of capital mobility is more apparent for higher values of $\psi$. Finally, conditioned on previous capital growth, both countries are better off in the second demographic shock compared to the first one, in terms of their welfare reactions.

\section{Alternative Aging Scenarios for Developing Regions}

The old-age dependency ratios in Figure 1 are based on population projections for more developed and developing regions in the next one hundred and fifty years. What happens if developing regions age sooner or later than embodied in these projections? Is the timing of developing country aging really important? This section addresses the implications of the timing of demographic shocks. We consider two alternative scenarios. In the first scenario, country B ages a period sooner, so the second demographic shock is introduced in period 2 rather than in

period 3. In the second scenario, country B ages a period later, so the shock is introduced in period 4. Figures 10 and 11 show the welfare transitions for country A and country B under these alternative aging scenarios. 
The pattern of the effects changes significantly with the timing of aging. In the early aging scenario, both countries enjoy higher welfare after period 1 compared to other scenarios. Whereas in the late aging scenario, there is considerable welfare reduction for both countries in period 3. This scenario produces the lowest welfare transition in both countries after period 2 compared to other scenarios. This unattractive implication can be understood by examining the capital stock transitions in Figures 12 and 13. After an initial boost from the first demographic shock, capital per worker actually decreases in both countries in period 3 in our late aging scenario. The main reason for this is that the effect of an initial increase in savings that drives capital accumulation (direct saving effect) dissipates and diminishes over time unless there is another similar shock. We see that the decrease in capital per worker occurs one period before the second demographic shock. We also see that capital per worker increases again in both countries in period 4 . These findings suggest that the timing of developing country aging has strong welfare implications for both countries in their transitions to a new steady state. An early aging scenario seems to provide favorable welfare transitions for both countries.

\section{Conclusion}

In this paper, we examined the transition effects of a worldwide trend in population aging in more developed regions that is expected to be followed by developing regions in the near future. By changing the political balances in favor of the preferences of older generations, population aging has a direct impact on government spending policy. This triggers changes in the economy of both the aging country and other regions through the medium of internationally mobile capital. The analytical and numerical simulation exercises show that capital mobility and an endogenous fiscal policy together have a substantial influence on the economic transitions of aging countries. While capital mobility has consumption and welfare smoothing effects, 
endogenous fiscal policy is the key factor in creating asymmetries between regions. Our results also show that even though the demographic shocks that we considered are symmetric, the reactions to these shocks are quite different. The second demographic shock overall produces more favorable economic outcomes for both regions. Finally, in an attempt to examine the implications of the timing of developing country aging, we considered an early aging and a late aging scenario. Our simulations indicate that an early aging scenario is more beneficial, in terms of long term welfare, for both regions. 


\section{Appendix}

\section{Stability}

\section{Stability of the Political Equilibrium}

The political equilibrium is locally stable if starting from a given level of government spending ( $g$ ), the economy moves automatically to an equilibrium (Holtz-Eakin, Lovely, and Tosun 2000). For an analysis of stability, I assume a Marshallian-type adjustment rule:

$$
\frac{d g}{d t}=c\left[\frac{\tau_{p}}{\tau}-1\right]=\varphi(g)
$$

In this expression $c$ is a positive constant. The variable $\tau$ is the actual tax rate, which is a function of government spending per worker and income per worker. The variable $\tau_{p}$ is median voter's preferred tax rate for a given level of government spending and income. Equation (A.1) states that if median voter's preferred tax rate exceeds actual tax rate, government spending will rise. For a political equilibrium, $\varphi(\hat{g})=0$ and $\hat{g}$ is locally stable if and only if $\varphi^{\prime}(\hat{g})<0$ (where $\hat{g}$ is the equilibrium level of government spending). Differentiating (8), (10) and (14) in the text, we get:

$$
d \tau_{t p}=\frac{1}{y^{*}}(1-\alpha) \varepsilon_{h g} \varepsilon_{\tau y} d g_{t}
$$

Differentiating the government budget constraint $\left(\tau_{t} y_{t}=g_{t}\right)$ and using the differentiated form of (10), we get:

$$
d \tau_{t}=\frac{\left[1-(1-\alpha) \varepsilon_{h g}\right]}{y^{*}} d g_{t}
$$

Finally, differentiating (A.1) and using (A.2) and (A.3), we get the stability condition for political equilibrium: 


$$
1-\left[(1-\alpha) \varepsilon_{h g}\left(1+\varepsilon_{\tau y}\right)\right]>0
$$

This makes $P$ in the text positive.

\section{Stability of the Intertemporal Equilibrium}

B.1 Intertemporal stability requires that the eigen value of the matrix $\Omega_{2 x 2}$ in (19) is less than 1 in absolute value. Eigen value is found by solving $|\Omega-\lambda I|=0$, where $\lambda$ is the eigen value and $I_{2 x 2}$ is the identity matrix. The two possible values of $\lambda$ are:

$$
\lambda=0 \text { or } \lambda=2 M=\frac{\alpha\left(1-\frac{\tau^{*}}{1-\tau^{*}} \varepsilon_{\text {yy }}\right)}{P}
$$

Using the nonzero root, the intertemporal stability requires:

$$
|\lambda|<1 \text { or }|2 M|=\left|\frac{\alpha\left(1-\frac{\tau^{*}}{1-\tau^{*}} \varepsilon_{\tau y}\right)}{P}\right|<1
$$

However, since $\varepsilon_{\tau y}<\frac{1-\tau}{\tau}$ (as shown in the proof below) and $P>0$ by political stability, $2 M$ is positive and the intertemporal stability condition can be written as:

$$
\alpha\left(1-\frac{\tau^{*}}{1-\tau^{*}} \varepsilon_{\tau y}\right)<P
$$

\section{B.2 $2 M>0$}

Proof by contradiction: Let $\varepsilon_{\tau y} \geq \frac{1-\tau}{\tau}$,

Since $\varepsilon_{\tau y}=\frac{1}{m \psi y-1}$

and

$$
\frac{1}{m \psi y-1} \geq \frac{1}{\tau}-1
$$


then

$$
\frac{m \psi y}{m \psi y-1} \geq \frac{(1+\psi) m y}{m \psi y-1}
$$

which can not be true since $m \psi y-1>0$ and $\psi>0, m>0, y>0$.

Then $\varepsilon_{\tau y}<\frac{1-\tau}{\tau}$ which implies $2 M>0$.

\section{The Effect of Increasing Dependency Ratio on the Ability Level of the Median Voter}

Recall that median voter is defined by $N_{t-1}+N_{t} \int_{0}^{m} f(a) d a=\frac{N_{t-1}+N_{t}}{2}$. Rewriting this:

$N_{t-1}+N_{t} F(m)-N_{t} F(0)=\frac{N_{t-1}+N_{t}}{2}$, dividing both sides by $N_{t-1}$ :

$1+\left(1+\eta_{t}\right)\{F(m)-F(0)\}=\frac{2+\eta_{t}}{2}$ which can be rearranged as $F(m)-F(0)=\frac{\eta_{t}}{2\left(1+\eta_{t}\right)}$.

Differentiating both sides we get, $F^{\prime}(m) d m=\frac{2\left(1+\eta_{t}\right) d \eta_{t}-2 \eta_{t} d \eta_{t}}{4\left(1+\eta_{t}\right)^{2}}$. Finally this can be

rearranged as $\frac{d m}{d \eta_{t}}=\frac{2}{F^{\prime}(m) 4\left(1+\eta_{t}\right)^{2}}$ which is positive. Therefore, with a decrease in the $(+)$

population growth rate the ability level of the median voter decreases. 


\section{Endnotes}

* I am grateful to Douglas J. Holtz-Eakin and Mary E. Lovely for their helpful comments and encouragement. I benefited from discussions with the participants of the conference on "Policy Evaluation with Computable General Equilibrium Models," University of Genova, Italy, 29-30 October, 1999. I also thank Syracuse University Economics/Public Administration Graduate Seminar participants. All errors are my responsibility.

1. The political process can be modeled using a median voter framework because the conditions for the median voter theorem are satisfied. The choice of voters is over a single dimension since the preferred tax rate is the only choice variable. The preferences are single peaked.

2. In a world with divergent population growth, the region with the higher growth rate continuously gets bigger than the other region. In that case, the post-demographic shock steady state is not defined, making an analytical study impossible.

3. See Diamond (1965)

4. The dependency ratio is defined as the ratio of elderly to non-elderly persons, $\left(N_{t-1} / N_{t}\right)=\left(1 / 1+\eta_{t}\right)$ where $\eta_{t}$ is the population growth rate. An increase in the dependency ratio is simulated by an exogenous decrease in the population growth rate $\eta_{t}$.

5. Since the balance of payments accounts are identical in absolute magnitudes, we can take out the country superscripts and present equations for one country.

6. Balance of trade is the difference between domestic product and domestic absorption and can be written as:

$$
B O T_{t}=y_{t}\left(1-\tau_{t}\right)-c_{1 t}-\frac{c_{2 t}}{1+\eta_{t}}-\left[\left(1+\eta_{t+1}\right) k_{t+1}-k_{t}\right]
$$

The net foreign income is earnings from net claims on foreign capital:

$$
F I_{t}=r_{t}\left(1-\tau_{t}\right)\left[\frac{s_{t-1}}{1+\eta_{t}}-k_{t}\right]
$$

7. Due to Cobb-Douglas, $\varepsilon_{\tau y}<\frac{1-\tau}{\tau}$ which means that $0<2 M<1$ (see appendix for the proof).

8. Due to the perfect symmetry of the initial and the final steady states, this open economy steady state formulation is identical to a one in closed economy. See Holtz-Eakin, Lovely and Tosun (2000) for a closed economy analysis. 
9. The denominator of (24) is positive since $2 M<1$ by dynamic stability.

10. By "direct" effect, we mean an effect independent of the change in the ability level of the median voter.

11. By "indirect" effect we mean an effect that is driven by a change in median voter's ability. This effect carries the political economy of population aging.

12. See Holtz-Eakin, Lovely and Tosun (2000) for a detailed analysis of this comparison.

13. $\varepsilon_{h g}=\left[\frac{\left(1+g^{*}\right)^{\psi}\left(\psi g^{*}-1\right)+1}{\left(1+g^{*}\right)^{\psi+1}-1}\right]$ and $\varepsilon_{\tau y}=\frac{1}{m \psi y-1}$

14. Net Interest rate effects embodied in $Z_{1}$ and $Z_{3}$ are different from the saving related effects $\left(Z_{2}\right.$ and $Z_{4}$ ) because saving is independent of interest rate due to Cobb-Douglas utility.

15. $Z_{1}=\frac{2\left[\alpha^{2} y^{*}\left[\left(1-\tau^{*}\right)-\varepsilon_{\tau y} \tau^{*}\right]-P y^{*}\left(1-\tau^{*}\right)\right]}{k^{* 2} P}=\frac{2 y^{*}\left(1-\tau^{*}\right)\left[\alpha^{2}\left[1-\frac{\varepsilon_{\tau y} \tau^{*}}{\left(1-\tau^{*}\right)}\right]-P\right]}{k^{*^{2} P}}<0$ since $\alpha\left[1-\frac{\varepsilon_{\tau y} \tau^{*}}{\left(1-\tau^{*}\right)}\right]<P$ by dynamic stability.

16. In contrast, we assume that both economies are at a steady state prior to the first demographic shock.

17. Generation $t$ refers to persons who are young in period $t$ and old in period $t+1$.

18. Unlike Cobb-Douglas, saving in the CRRA utility case is a function of the interest rate:

$$
S_{j t}=\frac{\theta_{i} w_{i} h_{i}}{1+(1+\delta) \frac{1}{\gamma}\left(1+r_{t+1} \theta_{t+1}\right) \frac{\gamma-1}{\gamma}} \text {. }
$$


Table1. Benchmark Values of the Parameters Used in the Two-Country OLG Model

\begin{tabular}{lcc}
\hline & $\begin{array}{c}\text { Rates Translated into } \\
\text { One-Period (30 Years) }\end{array}$ & Annual Rate \\
\hline Rate of time preference $(\delta)$ & 2.24 & 0.04 \\
Population growth rate $(\eta)$ & 0.55 & 0.02 \\
Elasticity of human capital w.r.t. inputs of & 0.50 & \\
ability and government spending $(\psi)$ & & \\
Elasticity of output w.r.t. capital $(\alpha)$ & 0.33 & \\
\hline Source: & &
\end{tabular}

Source: Computed by author. 
Table 2. Comparisons with Alternative Versions ${ }^{\mathrm{a}}$

\begin{tabular}{|c|c|c|c|c|c|c|}
\hline & \multirow[b]{3}{*}{ Time Periods } & \multicolumn{2}{|c|}{ Closed Economy } & \multicolumn{3}{|c|}{ Open Economy } \\
\hline & & \multirow[b]{2}{*}{$\begin{array}{c}\text { Country A } \\
\text { (1) }\end{array}$} & \multirow[b]{2}{*}{$\begin{array}{c}\text { Country B } \\
(2)\end{array}$} & \multirow{2}{*}{$\begin{array}{c}\text { Exogenous Policy } \\
\text { Country A and B } \\
\text { (3) }\end{array}$} & \multicolumn{2}{|c|}{ Endogenous Policy } \\
\hline & & & & & $\begin{array}{c}\text { Country A } \\
(4)\end{array}$ & $\begin{array}{c}\text { Country B } \\
\text { (5) }\end{array}$ \\
\hline \multirow{5}{*}{$\begin{array}{l}\text { Capital stock per } \\
\text { worker }\end{array}$} & 1 & 34.39 & 0.00 & 14.67 & 13.26 & 15.72 \\
\hline & 2 & 13.59 & 0.00 & 4.10 & 3.68 & 3.59 \\
\hline & 3 & 6.25 & 34.39 & 21.87 & 23.55 & 21.02 \\
\hline & 4 & 2.93 & 13.59 & 9.05 & 9.13 & 9.13 \\
\hline & steady state & 71.42 & 71.42 & 69.39 & 71.42 & 71.42 \\
\hline \multirow{5}{*}{$\begin{array}{l}\text { Human capital } \\
\text { per worker }\end{array}$} & 1 & -3.09 & 0.00 & 0.00 & -8.42 & 3.87 \\
\hline & 2 & 4.19 & 0.00 & 0.00 & 1.22 & 0.92 \\
\hline & 3 & 1.94 & -3.09 & 0.00 & 7.17 & -5.23 \\
\hline & 4 & 0.91 & 4.19 & 0.00 & 2.82 & 2.82 \\
\hline & steady state & 4.73 & 4.73 & 0.00 & 4.73 & 4.73 \\
\hline \multirow{5}{*}{$\begin{array}{l}\text { Income per } \\
\text { worker }\end{array}$} & 1 & 7.95 & 0.00 & 4.62 & -1.77 & 7.64 \\
\hline & 2 & 7.20 & 0.00 & 1.33 & 2.03 & 1.79 \\
\hline & 3 & 3.35 & 7.95 & 6.74 & 12.32 & 2.74 \\
\hline & 4 & 1.57 & 7.20 & 2.90 & 4.86 & 4.86 \\
\hline & steady state & 23.22 & 23.22 & 19.00 & 23.22 & 23.22 \\
\hline \multirow{5}{*}{$\begin{array}{l}\text { Government } \\
\text { spending per } \\
\text { worker }\end{array}$} & 1 & -7.25 & 0.00 & 0.00 & $=19.22$ & 9.41 \\
\hline & 2 & 10.33 & 0.00 & 0.00 & 3.03 & 2.17 \\
\hline & 3 & 4.66 & -7.25 & 0.00 & 18.27 & -11.94 \\
\hline & 4 & 2.17 & 10.33 & 0.00 & 6.85 & 6.85 \\
\hline & steady state & 11.56 & 11.56 & 0.00 & 11.56 & 11.56 \\
\hline \multirow{5}{*}{$\begin{array}{l}\text { Consumption of } \\
\text { young }\end{array}$} & 1 & 13.59 & 0.00 & 6.34 & 4.71 & 6.98 \\
\hline & 2 & 6.26 & 0.00 & 1.80 & 1.74 & 1.65 \\
\hline & 3 & 2.93 & 13.59 & 9.06 & 10.59 & 8.33 \\
\hline & 4 & 1.39 & 6.26 & 3.81 & 4.25 & 4.25 \\
\hline & steady state & 27.55 & 27.55 & 26.05 & 27.55 & 27.55 \\
\hline \multirow{5}{*}{$\begin{array}{l}\text { Consumption of } \\
\text { old }\end{array}$} & 1 & -12.24 & 0.00 & -5.75 & -5.97 & -5.97 \\
\hline & 2 & 8.00 & 0.00 & 4.51 & 3.18 & 5.42 \\
\hline & 3 & 3.76 & -12.24 & -6.49 & -6.52 & -6.61 \\
\hline & 4 & 1.78 & 8.00 & 5.10 & 6.86 & 4.68 \\
\hline & Steady state & 1.73 & 1.73 & 0.53 & 1.73 & 1.73 \\
\hline \multirow{6}{*}{ Welfare } & 0 & -3.93 & 0.00 & -1.80 & -1.90 & -1.90 \\
\hline & 1 & 16.25 & 0.00 & 7.79 & 5.60 & 8.81 \\
\hline & 2 & 7.54 & -3.93 & -0.29 & -0.36 & -0.46 \\
\hline & 3 & 3.52 & 16.25 & 10.76 & 13.03 & 9.81 \\
\hline & 4 & 1.66 & 7.54 & 4.49 & 5.10 & 5.10 \\
\hline & steady state & 28.31 & 28.31 & 26.25 & 28.31 & 28.31 \\
\hline
\end{tabular}

${ }^{a}$ All numbers are percentage changes from the previous period. Numbers for steady state indicate percentage change between the initial and the final steady state.

Source: Computed by author. 
Table 3. Sensitivity of Similar Results to Various Values of $\psi^{\text {a }}$

\begin{tabular}{|c|c|c|c|c|c|c|c|}
\hline & \multirow{2}{*}{$\begin{array}{c}\psi \\
\text { Time } \\
\text { Periods }\end{array}$} & \multicolumn{2}{|c|}{0.35} & \multicolumn{2}{|c|}{0.5} & \multicolumn{2}{|c|}{0.7} \\
\hline & & $\begin{array}{c}\text { Country A } \\
(1)\end{array}$ & $\begin{array}{c}\text { Country B } \\
\text { (2) }\end{array}$ & $\begin{array}{c}\text { Country A } \\
\text { (3) }\end{array}$ & $\begin{array}{c}\text { Country B } \\
(4)\end{array}$ & $\begin{array}{c}\text { Country A } \\
(5)\end{array}$ & $\begin{array}{c}\text { Country B } \\
(6)\end{array}$ \\
\hline \multirow{5}{*}{$\begin{array}{l}\text { Capital stock per } \\
\text { worker }\end{array}$} & 1 & 6.70 & 20.61 & 13.26 & 15.72 & 14.07 & 15.12 \\
\hline & 2 & -0.95 & -0.60 & 3.68 & 3.59 & 6.24 & 6.20 \\
\hline & 3 & 30.72 & 15.23 & 23.55 & 21.02 & 25.02 & 23.92 \\
\hline & 4 & 5.98 & 5.98 & 9.13 & 9.13 & 14.08 & 14.08 \\
\hline & steady state & 53.99 & 53.99 & 71.42 & 71.42 & 113.56 & 113.56 \\
\hline \multirow{5}{*}{$\begin{array}{l}\text { Human capital } \\
\text { per worker }\end{array}$} & 1 & -26.91 & 3.39 & -8.42 & 3.87 & 3.37 & 6.35 \\
\hline & 2 & -0.69 & -0.11 & 1.22 & 0.92 & 2.78 & 2.66 \\
\hline & 3 & 15.31 & -18.96 & 7.17 & -5.23 & 10.59 & 7.61 \\
\hline & 4 & 2.34 & 2.34 & 2.82 & 2.82 & 6.09 & 6.09 \\
\hline & steady state & -12.70 & -12.70 & 4.73 & 4.73 & 37.03 & 37.03 \\
\hline \multirow{5}{*}{$\begin{array}{l}\text { Income per } \\
\text { worker }\end{array}$} & 1 & -17.19 & 8.78 & -1.77 & 7.64 & 6.79 & 9.17 \\
\hline & 2 & -0.78 & -0.27 & 2.03 & 1.79 & 3.91 & 3.82 \\
\hline & 3 & 20.19 & -8.98 & 12.32 & 2.74 & 15.16 & 12.74 \\
\hline & 4 & 3.53 & 3.53 & 4.86 & 4.86 & 8.66 & 8.66 \\
\hline & steady state & 5.28 & 5.28 & 23.22 & 23.22 & 58.64 & 58.64 \\
\hline \multirow{5}{*}{$\begin{array}{l}\text { Government } \\
\text { spending per } \\
\text { worker }\end{array}$} & 1 & -91.63 & 15.98 & -19.22 & 9.41 & 4.97 & 9.42 \\
\hline & 2 & -14.02 & -0.46 & 3.03 & 2.17 & 4.08 & 3.91 \\
\hline & 3 & 419.65 & -67.62 & 18.27 & -11.94 & 15.81 & 11.29 \\
\hline & 4 & 16.96 & 16.96 & 6.85 & 6.85 & 8.99 & 8.99 \\
\hline & steady state & -50.73 & -50.72 & 11.56 & 11.56 & 58.24 & 58.24 \\
\hline \multirow{5}{*}{$\begin{array}{l}\text { Consumption of } \\
\text { young }\end{array}$} & 1 & -4.83 & 7.58 & 4.71 & 6.98 & 8.00 & 9.00 \\
\hline & 2 & -0.58 & -0.23 & 1.74 & 1.65 & 3.79 & 3.76 \\
\hline & 3 & 15.14 & 1.50 & 10.59 & 8.33 & 14.73 & 13.72 \\
\hline & 4 & 2.76 & 2.76 & 4.25 & 4.25 & 8.45 & 8.45 \\
\hline & steady state & 14.58 & 14.59 & 27.55 & 27.55 & 58.91 & 58.91 \\
\hline \multirow{5}{*}{$\begin{array}{l}\text { Consumption of } \\
\text { old }\end{array}$} & 1 & -8.54 & -8.54 & -5.97 & -5.97 & -4.21 & -4.21 \\
\hline & 2 & -4.56 & 7.89 & 3.18 & 5.42 & 6.05 & 7.04 \\
\hline & 3 & -9.73 & -9.42 & -6.52 & -6.61 & -2.85 & -2.89 \\
\hline & 4 & 12.53 & -0.81 & 6.86 & 4.68 & 10.42 & 9.44 \\
\hline & steady state & -8.61 & -8.61 & 1.73 & 1.73 & 26.75 & 26.75 \\
\hline \multirow{6}{*}{ Welfare } & 0 & -2.74 & -2.74 & -1.90 & -1.90 & -1.32 & -1.32 \\
\hline & 1 & -6.54 & 10.22 & 5.60 & 8.81 & 9.99 & 11.34 \\
\hline & 2 & -3.72 & -3.25 & -0.36 & -0.46 & 2.88 & 2.83 \\
\hline & 3 & 19.59 & 0.91 & 13.03 & 9.81 & 18.33 & 16.95 \\
\hline & 4 & 3.32 & 3.32 & 5.10 & 5.10 & 10.42 & 10.42 \\
\hline & steady state & 11.21 & 11.21 & 28.31 & 28.31 & 71.12 & 71.12 \\
\hline
\end{tabular}

${ }^{a}$ All numbers are percentage changes from the previous period. Numbers for steady state indicate percentage change between the initial and the final steady state.

Source: computed by author. 


\section{FIGURE 1}

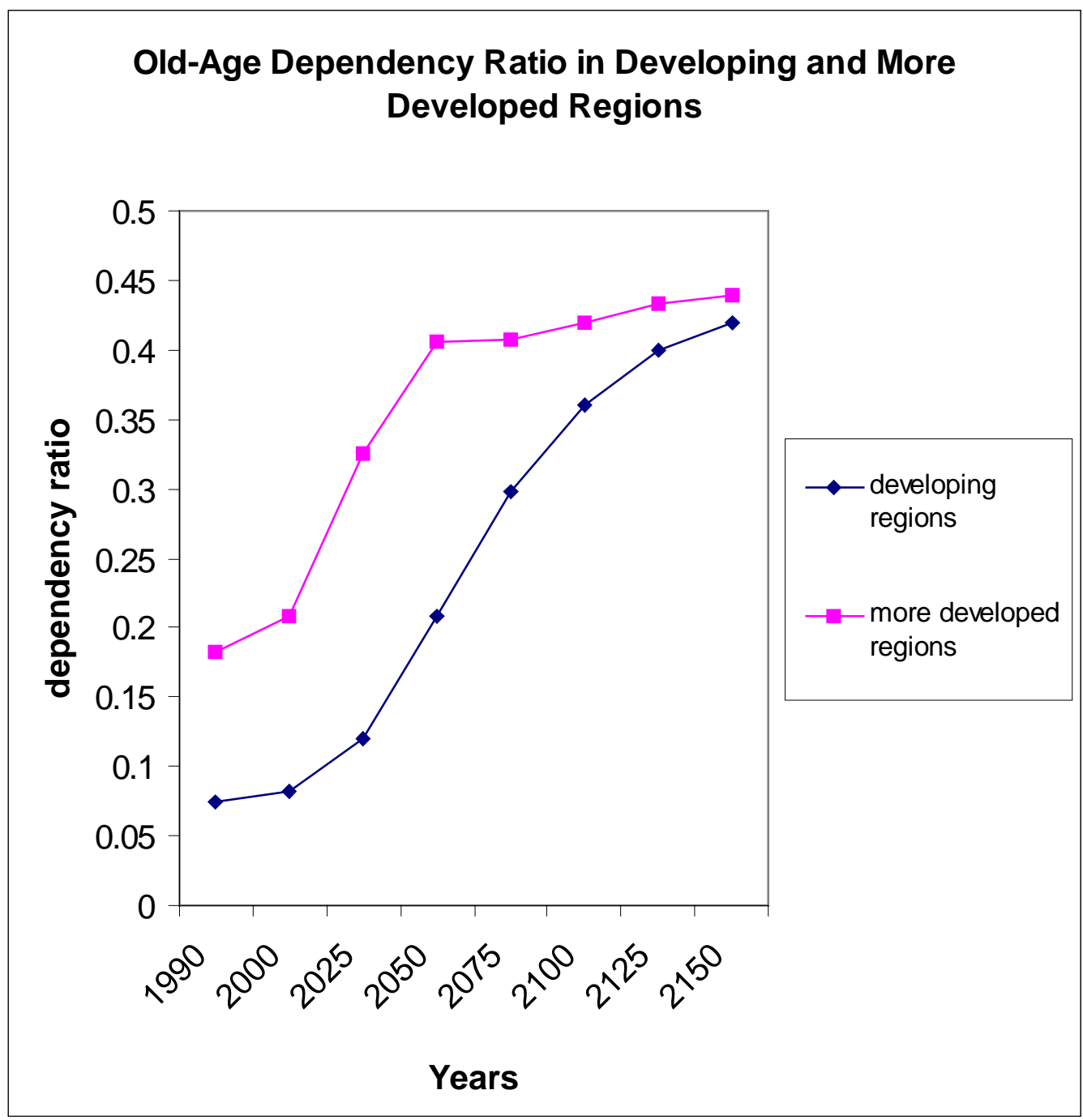

Source: World Population Projections (World Bank, 1994) and author's calculations. Note: Old-age dependency ratio is the proportion of population aged 65 and older to population aged 15-64. 

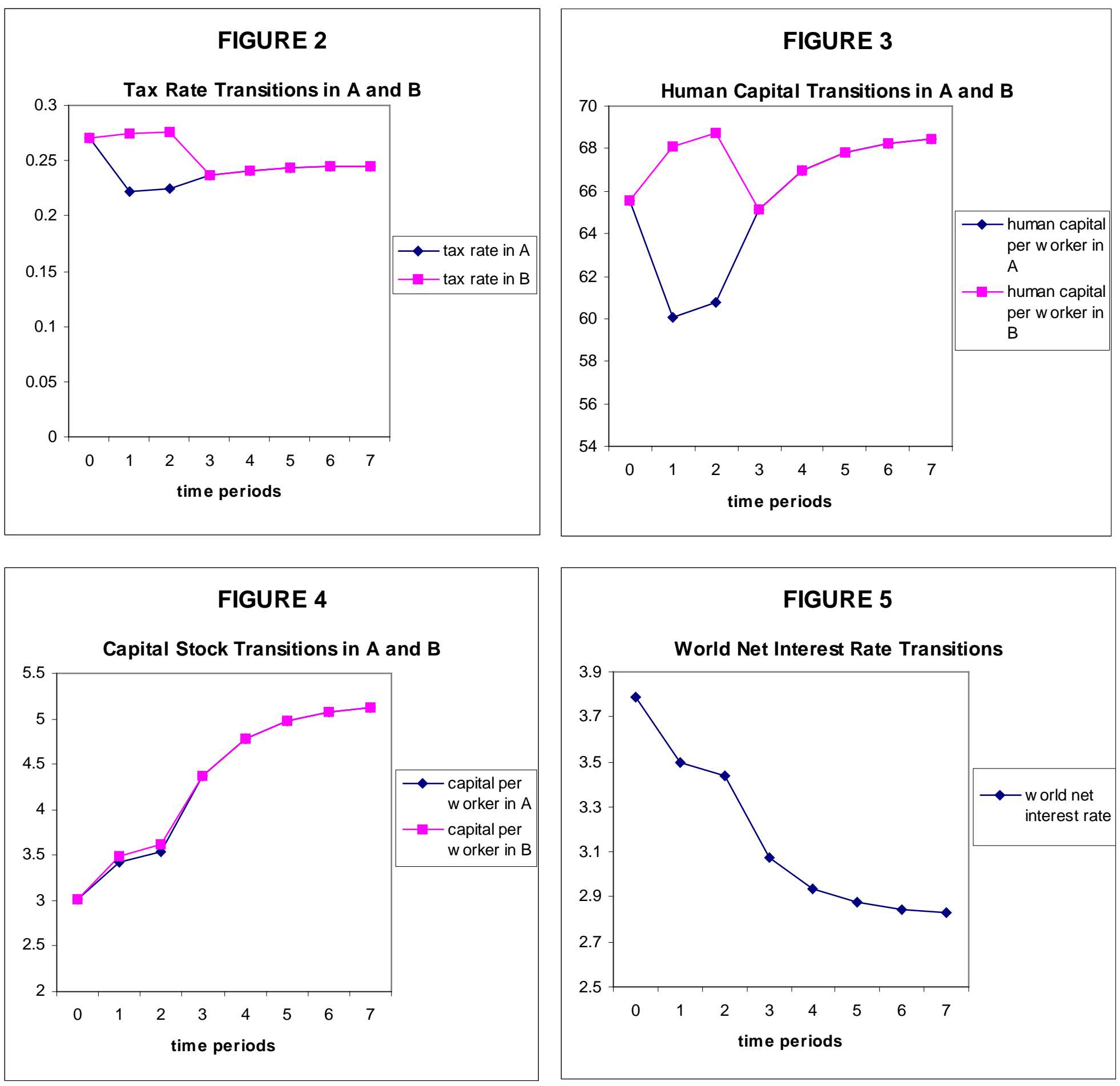


\section{FIGURE 6}

\section{Balance of Payments Transitions for Country A}
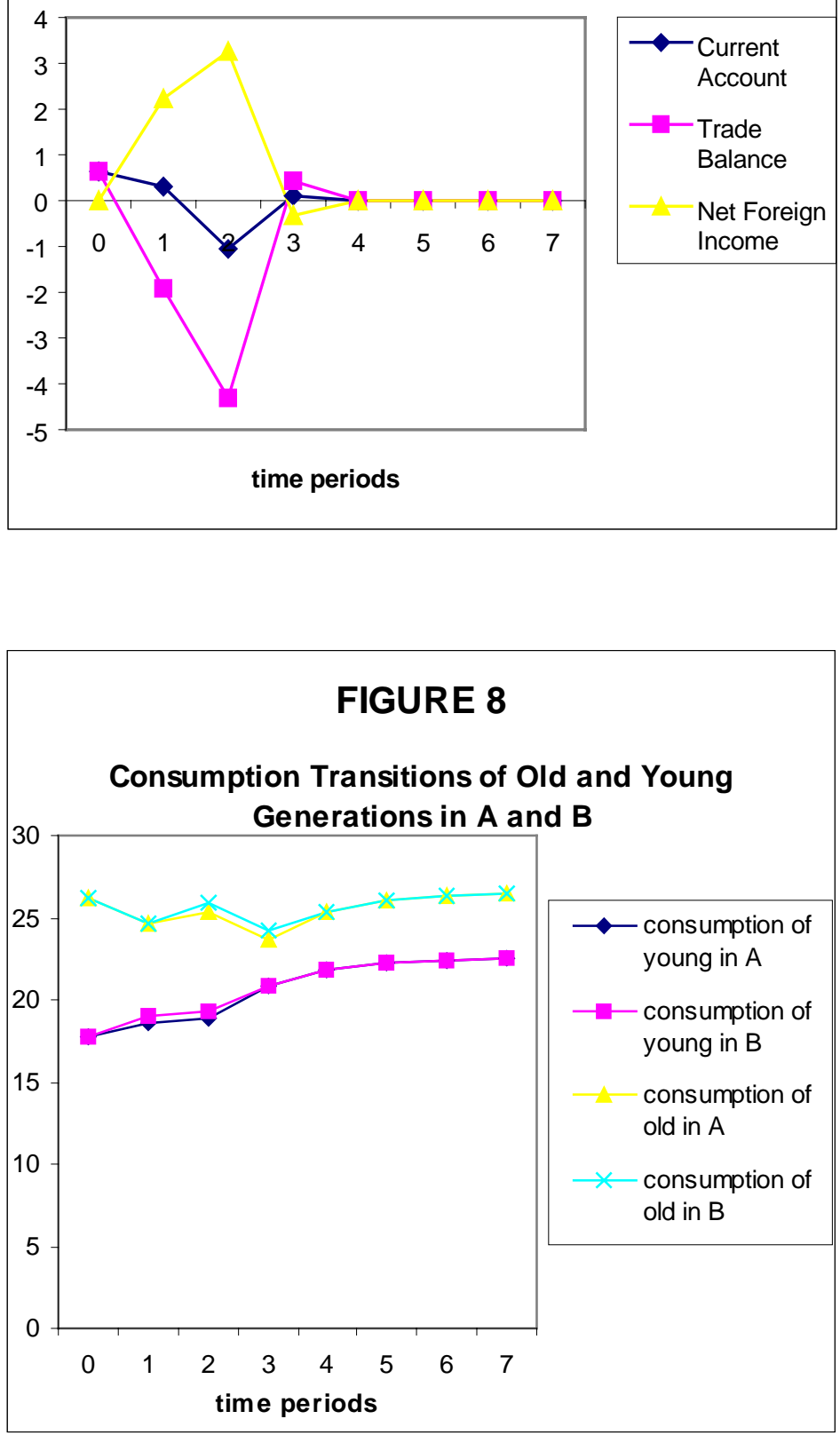

\section{FIGURE 7}

\section{Income Transitions in Country A and Country B}

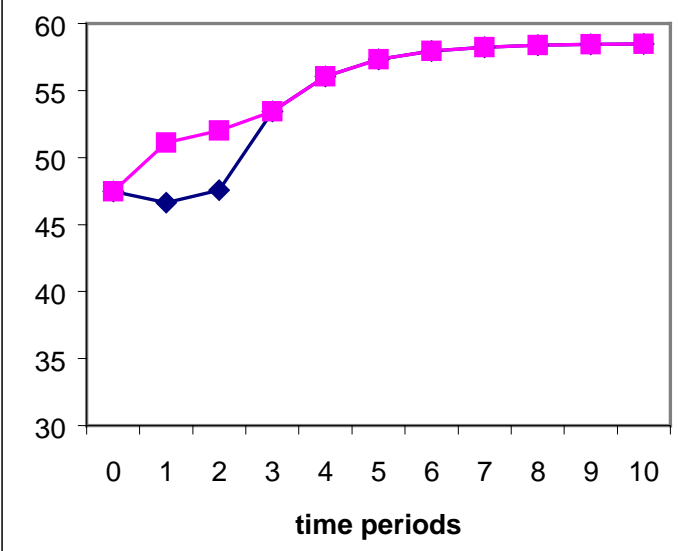

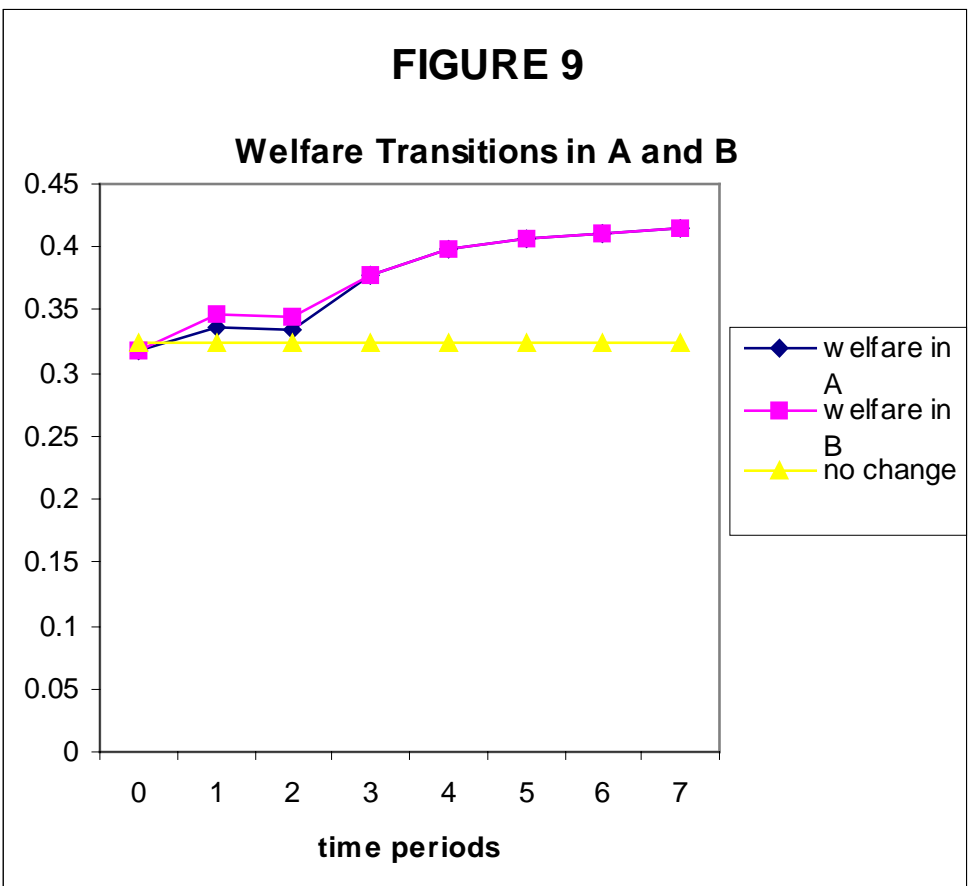



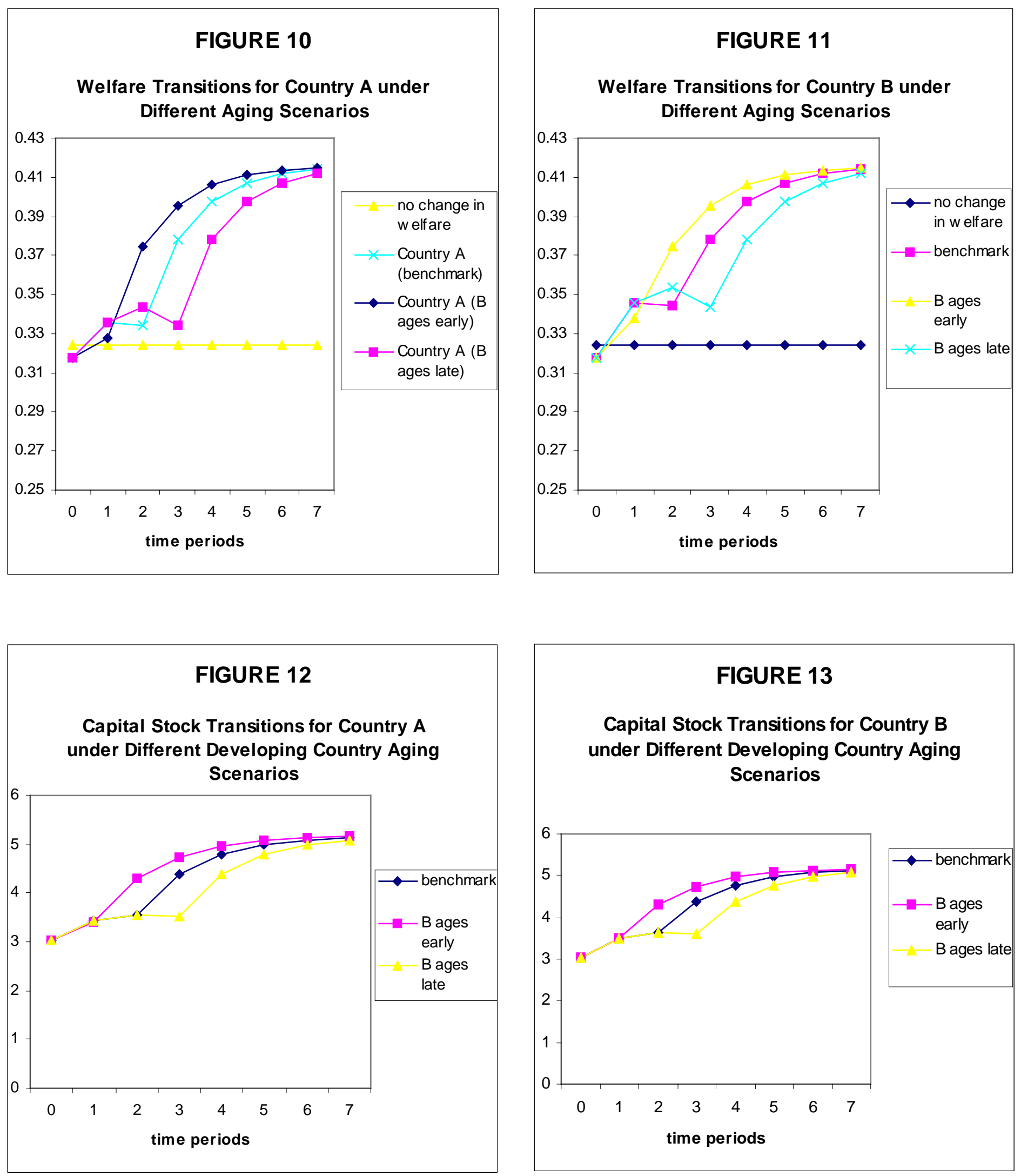


\section{References}

Börsch-Supan, A. 1996. "The Impact of Population Aging on Savings, Investment and Growth in the OECD Area." In Future Global Capital Shortages: Real Threat or Pure Fiction? Paris: Organisation for Economic Co-operation and Development, pp. 103-141.

Bos, E., M.T. Vu, E. Massiah, and R.A. Bulatao. 1994. World Population Projections. Baltimore, MD: The Johns Hopkins University.

Brooke, A., D. Kendrick, and A. Meeraus. 1996. GAMS: A User's Guide. Washington, DC: GAMS Development Corporation.

Buiter, W.H. 1981. "Time Preference and International Lending and Borrowing in an Overlapping Generations Model," Journal of Political Economy, 89(4): 769-797.

Cutler, D., J. Poterba, L. Sheiner, and L. Summers. 1990. “An Aging Society: Opportunity or Challenge," Brookings Papers on Economic Activity, 1: 1-73.

Holtz-Eakin, D., M.E. Lovely, and M.S. Tosun. 2000. "Generational Conflict, Human Capital Accumulation, and Economic Growth," working paper, Center for Policy Research, The Maxwell School. Syracuse, NY: Syracuse University.

Holtz-Eakin, D. 1993. "Demographics, Political Power and Economic Growth," Public Finance, 48 (Supplement): 349-365.

Kahn, M.E. 2000. "Demographic Change and the Demand for Environmental Regulation," working paper, Department of Economics. New York: Columbia University.

Masson, P.R. and R.W. Tryon. 1990. "Macroeconomic Effects of Projected Population Aging in Industrial Countries," IMF Staff Papers, 37(3): 453-485.

Meijdam, L. and H.A.A. Verbon. 1996. "Aging and Political Decision Making on Public Pensions," Journal of Population Economics, 9: 141-158.

Organisation for Economic Co-operation and Development. 1998. "Maintaining Prosperity in an Aging Society," Policy Brief No: 5. Paris: OECD.

Organisation for Economic Co-operation and Development. 1988. "Ageing Populations: The Social Policy Implications.” Paris: OECD.

Poterba, J.M. 1997. "Demographic Structure and the Political Economy of Public Education," Journal of Public Policy and Management, 16: 48-66.

Turner, D., C. Giorno, A. De Serres, A. Vourc'h, and P. Richardson. 1998. "Macroeconomic Implications of Ageing in a Global Context," OECD Working Paper AWP 1.2. Paris: OECD. 
United Nations. 1999. World Population Prospects: The 1998 Revision, Volume I: Comprehensive Tables. New York: United Nations. 